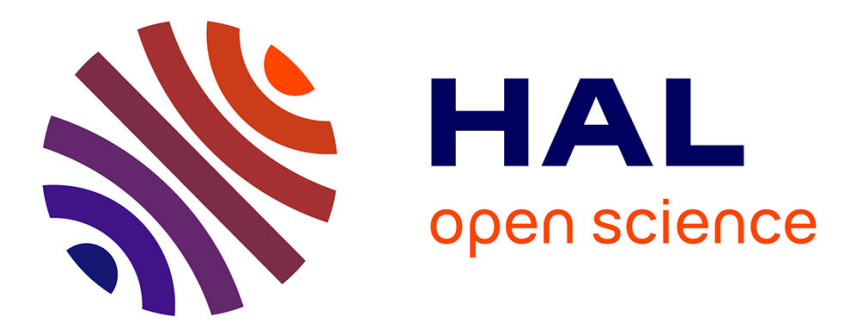

\title{
Down-regulation of hepatic lipase expression by elevation of cAMP in human hepatoma but not adrenocortical cells
}

Diederik van Deursen, Gert-Jan Botma, Hans Jansen, Adrie J.M. Verhoeven

\section{- To cite this version:}

Diederik van Deursen, Gert-Jan Botma, Hans Jansen, Adrie J.M. Verhoeven. Down-regulation of hepatic lipase expression by elevation of cAMP in human hepatoma but not adrenocortical cells. Molecular and Cellular Endocrinology, 2008, 294 (1-2), pp.37. 10.1016/j.mce.2008.07.004 . hal00532048

\section{HAL Id: hal-00532048 \\ https://hal.science/hal-00532048}

Submitted on 4 Nov 2010

HAL is a multi-disciplinary open access archive for the deposit and dissemination of scientific research documents, whether they are published or not. The documents may come from teaching and research institutions in France or abroad, or from public or private research centers.
L'archive ouverte pluridisciplinaire HAL, est destinée au dépôt et à la diffusion de documents scientifiques de niveau recherche, publiés ou non, émanant des établissements d'enseignement et de recherche français ou étrangers, des laboratoires publics ou privés. 


\section{Accepted Manuscript}

Title: Down-regulation of hepatic lipase expression by elevation of cAMP in human hepatoma but not adrenocortical cells

Authors: Diederik van Deursen, Gert-Jan Botma, Hans Jansen, Adrie J.M. Verhoeven

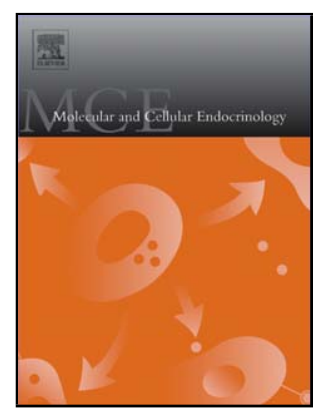

PII: S0303-7207(08)00290-6

DOI: doi:10.1016/j.mce.2008.07.004

Reference: MCE 6919

To appear in: $\quad$ Molecular and Cellular Endocrinology

Received date: $\quad$ 5-11-2007

Revised date: $\quad 12-6-2008$

Accepted date: $\quad 6-7-2008$

Please cite this article as: van Deursen, D., Botma, G.-J., Jansen, H., Verhoeven, A.J.M., Down-regulation of hepatic lipase expression by elevation of cAMP in human hepatoma but not adrenocortical cells, Molecular and Cellular Endocrinology (2007), doi:10.1016/j.mce.2008.07.004

This is a PDF file of an unedited manuscript that has been accepted for publication. As a service to our customers we are providing this early version of the manuscript. The manuscript will undergo copyediting, typesetting, and review of the resulting proof before it is published in its final form. Please note that during the production process errors may be discovered which could affect the content, and all legal disclaimers that apply to the journal pertain. 


\section{DOWN-REGULATION OF HEPATIC LIPASE EXPRESSION BY ELEVATION OF CAMP IN HUMAN HEPATOMA BUT NOT ADRENOCORTICAL CELLS.}

Diederik van Deursen, Gert-Jan Botma, Hans Jansen, Adrie J.M. Verhoeven

Cardiovascular Research School COEUR,

Dept. Biochemistry, Erasmus MC Rotterdam, Netherlands

\section{Correspondence:}

AJM Verhoeven, $\mathrm{PhD}$

Dept. Biochemistry, Erasmus MC

PO Box 2040

3000 CA Rotterdam

Netherlands

Phone: +31.10 .7043331 ; fax: +31.10 .7044747$

e-mail: a.verhoeven@erasmusmc.nl

\footnotetext{
ABBREVIATIONS:

Br-cAMP: 8-bromo-cyclic AMP; CAT: chloramphenicol acyltransferase; DMEM:

Dulbecco's modified Eagle's medium; HDL and LDL: high- and low-density lipoproteins; HL: hepatic lipase; PBS: phosphate-buffered saline; PMSF:

phenylmethylsulfonylfluoride
} 


\begin{abstract}
Expression of hepatic lipase (HL) in the liver is reduced during prolonged fasting. This effect is mainly mediated via catecholamines, which signal through elevation of $\mathrm{Ca}^{2+}{ }_{\mathrm{i}}$ as well as cAMP. We have studied the effect of cAMP on HL expression in cell culture. Overnight incubation of HepG2 cells with 10-300 $\mu \mathrm{M}$ 8-bromo-cyclic AMP resulted in a dose-dependent, up to $50 \%$ reduction in secretion of HL, but had no effect on secretion of $\alpha_{1}$-antitrypsin or overall protein synthesis. HL mRNA levels were decreased 1.5 fold, as determined by semi-quantitative and real-time RT-PCR. In HepG2 cells transiently transfected with human HL (-685/+13) or rat HL (-446/+9) promoter-reporter constructs, cAMP induced a similar dose-dependent suppression of HL promoter activity. cAMP responsiveness in HepG2 cells was mediated by a conserved 10-bp response element at $-45 /-36$, that represents a potential binding site for CCAAT/enhancer-binding protein beta (C/EBP $\beta)$. cAMP reduced expression of the $45 \mathrm{kDa} \mathrm{C} / \mathrm{EBP} \beta$ protein and binding of $\mathrm{C} / \mathrm{EBP} \beta$ to the proximal promoter region of the human HL gene by $50 \%$, as determined by immunoblotting and chromatin immunoprecipitation assay, respectively. In human H295R adrenocortical cells, cAMP failed to suppress HL promoter activity, and only slightly reduced C/EBP $\beta$ expression. We conclude that the fall in HL expression during prolonged fasting may be mediated through elevation of cAMP and lowering of C/EBP $\beta$ expression.
\end{abstract}




\section{Introduction}

Hepatic lipase (HL; EC 3.1.1.3) is a lipolytic enzyme that is synthesized and secreted almost exclusively by liver parenchymal cells (reviewed in (Jansen et al., 2002; Perret et al., 2002). The protein is bound extracellularly to the liver at heparin-sensitive sites, where it plays an important role in the metabolism of plasma lipoproteins. HL mediates the conversion of cholesterol-enriched $\mathrm{HDL}_{2}$ to cholesterol-poor $\mathrm{HDL}_{3}$ and the formation of small dense LDL from large buoyant LDL, and HL plays a role in postprandial lipid transport by facilitating the clearance of remnant lipoproteins by the liver (Jansen et al., 2002). Hepatic lipase activity is also expressed in adrenals and ovaries, where the enzyme may play a role in delivery of HDL cholesterol for steroidogenesis (Jansen and de Greef, 1988; Vieira-van Bruggen et al., 1998). The amount of HL in human post-heparin plasma is influenced by genetic (Isaacs et al., 2004; Jansen et al., 1997), hormonal and nutritional factors (Perret et al., 2002), as well as by body composition (Carr et al., 1999; Despres et al., 1989; Nie et al., 1998).

Several studies in humans suggest that HL activity varies in parallel with insulin levels (Perret et al., 2002). HL activity increases with fasting plasma insulin levels in non-diabetic, normocholesterolemic coronary artery disease patients (Jansen et al., 1997), and plasma HL activity is positively correlated with increased plasma insulin levels in response to an oral glucose load (Katzel et al., 1992; Pollare et al., 1991). HL activity is elevated under conditions with high plasma insulin, such as in type 2 diabetes (Baynes et al., 1991) and obesity-related hyperinsulinaemia (Cominacini et al., 1993). However, in glycemic clamp studies with normal and type 2 diabetic men insulin administration caused a decrease in hepatic lipase activity (Baynes et al., 1992). In vitro studies have not shown a clear upregulation of HL expression by insulin (Jensen et al., 1989). Hence, there is currently no evidence for a direct upregulation of human HL expression by insulin.

In rats, post-heparin plasma HL activity is strongly depressed during fasting (Peinado-Onsurbe et al., 1991, 2000). This effect has been attributed to the increased catecholamine levels during fasting (Peinado-Onsurbe et al., 1991). Indeed, in vitro studies with rat hepatocytes show an acute inhibition of HL secretion by $\alpha_{1 \mathrm{~B}}$ adrenergic agonists at the post-transcriptional level (Neve et al., 1998; Peinado- 
Onsurbe et al., 1991, 2000), mainly through the mobilization of intracellular $\mathrm{Ca}^{2+}$ (Neve et al., 1997, 1998). However, $\alpha_{1 \mathrm{~B}}$-adrenergic agonists also increase the generation of cAMP in liver cells (Morgan et al., 1983; Nomura et al., 1993), and cAMP elevation in rat hepatocytes has been shown to inhibit secretion of HL activity (Klin et al., 1996). In addition, overnight but not short-term treatment of freshly isolated rat hepatocytes with glucagon, which predominantly signals through elevation of cAMP, has been shown to decrease HL secretion (Jensen et al., 1989; Peinado-Onsurbe et al., 1991; Schoonderwoerd et al., 1984). In vivo, glucagon levels in portal blood vary oppositely to insulin levels, and catecholamines increase glucagon secretion into portal blood. We hypothesize therefore, that hepatic lipase secretion is increased in parallel with insulin, due to the opposite changes in catecholamines and glucagon, and through signaling via intracellular cAMP. In this study, we examined the mechanism by which elevation of cAMP reduces human hepatic lipase expression using HepG2 hepatoma cells as model system. HepG2 cells express only few $\alpha_{1 B^{-}}$or $\beta$-receptors (Kost et al., 1992; Sanae et al., 1992). In addition, most studies suggest that glucagon receptors are markedly downregulated in hepatoma cells (Hornbuckle et al., 2004; Mirel et al., 1978). We therefore used membrane-permeant cAMP to study the effect of receptors that signal through this second messenger. 


\section{Materials and methods}

\subsection{Materials}

8-Bromo-cAMP (Br-cAMP) and 8-bromo-cGMP (Br-cGMP) were purchased from Sigma (St. Louis, IL, USA), and dibutyryl-cAMP (db-cAMP), cycloheximide, Trasylol and restriction enzymes were from Roche (Germany). PMSF was from Merck (Darmstadt, Germany). Media, fetal bovine serum and $\operatorname{Tran}^{35} \mathrm{~S}$ label (1100 $\mathrm{Ci} / \mathrm{mmol}$ ) were from ICN (Costa Mesa, CA, USA). Glycerol trioleate (50-80 $\mathrm{mCi} / \mathrm{mmol}),\left[\alpha_{-}{ }^{32} \mathrm{P}\right] \mathrm{dCTP}$, the Megaprime DNA labelling kit, Hybond-filters, and horseradish peroxidase-conjugated donkey anti-rabbit IgG and Hyper ECL film were all from Amersham Pharmacia Biotec (Amersham, U.K.). Heparin was obtained from Leo Pharmaceuticals (Weesp, Holland). Rabbit antibodies against human $\alpha_{1^{-}}$ antitrypsin and Zysorbin (formaldehyde-fixed Staphylococcus aureus membranes) were from Dakopatts (Glostrup, Denmark) and Zymed Laboratories (San Francisco, CA, USA), respectively. Rabbit antibodies against C/EBP $\beta$ (C-19) and B23 (nucleophosmin, a nucleolar marker protein) were from Santa Cruz Biotechnology (Santa Cruz, CA, USA). Super Signal West Pico Chemiluminescent Substrate was from Pierce, Rockford, IL, USA). Oligonucleotides were custom-made by Eurogentec (Seraing, Belgium). Other chemicals were from Sigma.

\subsection{HepG2 cell culture and hepatic lipase secretion}

Human hepatoma HepG2 cells were grown as monolayer cultures in DMEM supplemented with $10 \%$ (by vol) fetal bovine serum at $37^{\circ} \mathrm{C}$ in a humidified air/ $\mathrm{CO}_{2}$ (19:1) atmosphere. The cells were split 1:10 into new flasks once a week. Medium was refreshed once a week. For secretion experiments, cells were seeded into six-well plates. At confluence, the medium was replaced by $1 \mathrm{ml}$ of fresh medium containing $25 \mathrm{U} / \mathrm{ml}$ heparin. Incubations were started with the addition of Br-cAMP and continued for $16 \mathrm{~h}$, unless otherwise stated. Then, the medium was collected on ice for analysis of secreted HL activity.

$\mathrm{HL}$ activity was determined by a triacylglycerol hydrolase assay at $\mathrm{pH} 8.5$ in $0.6 \mathrm{M} \mathrm{NaCl}$ with a gum acacia-stabilized glycerol $\left[{ }^{14} \mathrm{C}\right]$ trioleate emulsion as substrate 
(Verhoeven and Jansen, 1990). Activities are expressed as m-units (nmol of free fatty acids released per min). Of total lipase activity in the media, more than $95 \%$ was sensitive to inhibition by polyclonal anti-human HL IgG's (Verhoeven and Jansen, 1990).

\section{3. $\alpha_{1}$-Antitrypsin and total protein synthesis}

Synthesis and secretion of $\alpha_{1}$-antitrypsin was measured by the incorporation of $\left[{ }^{35}\right.$ S $]$ methionine into immunoprecipitated protein (Verhoeven et al., 1999). HepG2 cells were incubated overnight in normal medium containing $80 \mu \mathrm{Ci} / \mathrm{ml}$ of $\operatorname{Tran}^{35} \mathrm{~S}$ label with or without Br-cAMP. Then, the culture plates were put on ice, and the medium was collected into vials containing unlabelled methionine ( $1 \mathrm{mM}$ final concentration) and a cocktail of protease inhibitors (1 mM EDTA, 10 units/ml Trasylol, $0.1 \mathrm{mM}$ benzamidine, $2 \mu \mathrm{g} / \mathrm{ml}$ leupeptin, $2 \mu \mathrm{g} / \mathrm{ml}$ antipain, $2 \mu \mathrm{g} / \mathrm{ml}$ chymostatin and $2 \mu \mathrm{g} / \mathrm{ml}$ pepstatin; all final concentrations). The medium was incubated for $15 \mathrm{~min}$ (on ice) with Zysorbin in the presence of $0.2 \mathrm{mg} / \mathrm{ml}$ human serum albumin and centrifuged (10 $\min 10,000 \mathrm{~g})$ to remove material that bound nonspecifically to the Protein A. The supernatants were then incubated for $1 \mathrm{~h}\left(4^{\circ} \mathrm{C}\right)$ with rabbit anti-human $\alpha_{1}$-antitrypsin (1:100), followed by overnight incubation with Zysorbin. After centrifugation, the pellets were washed twice in phosphate-buffered saline (PBS) containing 1\% (v/v) Triton X-100, 0.25\% sodium deoxycholate and 1 mM PMSF, and twice in PBS. The pellets were resuspended in Laemmli's sample buffer, and after boiling for $5 \mathrm{~min}$, the precipitated proteins were separated by SDS/PAGE (7.5\% gel). The ${ }^{35} \mathrm{~S}$-labelled proteins were visualized by exposure of the dried gels to a phosphor screen (GS-393 Molecular Imaging System; Bio-Rad, Hercules, CA, USA).

Incorporation of $\left[{ }^{35} \mathrm{~S}\right]$ methionine into trichloroacetic acid-precipitable material was taken as a measure of total protein synthesis. HepG2 cells were incubated with $\operatorname{Tran}{ }^{35} \mathrm{~S}$-label, and cell-free medium was prepared, as described above. The cells in the wells were washed twice in PBS, then lysed in PBS containing 1\% Triton X-100, $1 \%$ sodium deoxycholate, $1 \mathrm{mM}$ methionine, $10 \mathrm{mM}$ Hepes $(\mathrm{pH} 7.4)$ and the protease inhibitor cocktail described above. After $30 \mathrm{~min}$ on ice, the lysate was collected from the wells, and the lysate was cleared by centrifugation for $10 \mathrm{~min}$ at $10,000 \mathrm{~g}$. Aliquots 
$(5 \mu 1)$ of the cell-free medium and the cleared lysate were spotted in triplicate onto Whatmann 3MM filters, and the radioactivity on the filters was quantified by phosphor imaging, without or with treatment with boiling trichloroacetic acid (Verhoeven and Jansen, 1990).

\subsection{Quantification of HL mRNA.}

Total RNA was isolated from the HepG2 cells with phenol/guanidinium isothiocyanate (Chomczynski and Sacchi, 1987). RNA was quantified by spectrophotometry at $260 \mathrm{~nm}$. The amount of HL mRNA was determined by semiquantitative and by real-time RT-PCR. For the former method, a single-tube RT-PCR was performed using 5'-GTG GGC ATC AAA CAG CCC-3' as forward and 5'-CAG ACA TTG GCC CAC ACT G-3' as reverse primer, and known amounts of in-vitro generated HL cRNA lacking an internal $80 \mathrm{bp}$-fragment, as described previously (Verhoeven et al., 1994). Real-time quantitative PCR analysis was performed using the MyIQ single color real-time PCR Detection system (Bio-Rad). First, $4 \mu \mathrm{g}$ total RNA was reverse transcribed using random hexamer primers and M-MLV Reverse Transcriptase (Promega, Leiden, Netherlands) in a final volume of $50 \mu \mathrm{l}$. cDNA ( $2 \mu \mathrm{l})$ was added in a $25 \mu \mathrm{l}$ final volume containing $0.2 \mathrm{mM}$ dNTPs, 0.5 U Platinum Taq DNA polymerase (Invitrogen), $3 \mathrm{mM} \mathrm{MgCl}_{2}, 0.4 \mu \mathrm{M}$ of forward and reverse primers, and $0.15 x$ SYBR Green I (Sigma). The PCR program consisted of a denaturing step (3 $\min 95^{\circ} \mathrm{C}$ ), followed by 40 cycles of $15 \mathrm{sec}$ at $95^{\circ} \mathrm{C}$ and $45 \mathrm{sec}$ at $60^{\circ} \mathrm{C}$. The relative abundance of HL mRNA was determined by the $\Delta \mathrm{C}_{\mathrm{T}}$ method using the efficiency of amplification derived from the log-linear part of the PCR. HL mRNA levels were normalized to acidic ribosomal phosphoprotein PO (36B4) mRNA. Primers used were: HL forward: 5'-ATC GCC GTC CGC AAC ACC-3' (nt 394-411, numbering according to the coding sequence (Datta et al., 1988)); HL reverse: 5'-ACC CAG CTG TAC CCA ATT AGG-3' (nt 510-489); 36B4 forward: 5'-CCT TCT TGG CTG ATC CAT CTG C-3' (nt 877-898, numbering according to the cDNA sequence (Rich and Steitz, 1987)); 36B4 reverse: 5'-CCG ACT CCT CCG ACT CTT CC-3'(nt 980999). 


\subsection{Human and rat HL promoter-reporter constructs}

Human and rat HL promoter fragments were generated and subcloned into the pGL3basic luciferase or the pCAT-Basic reporter vector (Promega) as detailed elsewhere (van Deursen et al., 2007). All human and rat HL promoter fragments extended to +13 and +9 at their 3'-end, respectively. From the human HL-685 luciferase plasmid, a promoter construct lacking the internal $-45 /-36$ sequence was generated by the PCR overlay technique (Higuchi et al., 1988), using 5'-TTA TTA AAT GGG CAG T-A AAG TAT CTA ATA GGC-3' and 5'-ATT AGA TAC TTT -AC TGC CCA TTA ATA ATT A-3' as forward and reverse mutagenic primers, respectively, in combination with two plasmid specific primers. All inserts in pGL3-Basic and pCATBasic were verified by cycle sequencing using the Thermo Sequenase dye terminator kit (Amersham) and the ABI 377 sequencer. Plasmid DNAs were isolated with the Wizard Midiprep System (Promega).

\subsection{Transfection assays in HepG2 cells}

Transfection of HepG2 cells with CAT-reporter constructs was performed by the calcium-phosphate co-precipitation method. At $24 \mathrm{~h}$ before transfection, the cells were plated in 6-wells plates at $30 \%$ confluence. At $3 \mathrm{~h}$ before transfection, the medium was refreshed. Cells were co-transfected with $2.5 \mu \mathrm{g} / \mathrm{well}$ of the CAT reporter test plasmid and $0.2 \mu \mathrm{g} /$ well of control RSV $\beta$-galactosidase expression plasmid (Promega) (Botma et al., 2001). Parallel transfections with SV40-CATControl and empty pCAT-Basic plasmids were used as positive and negative controls, respectively. At $3 \mathrm{~h}$ and $24 \mathrm{~h}$ after transfection, the medium was refreshed and test agents were added to the fresh medium. Fourty-eight hours post-transfection, cell lysates were prepared. CAT and $\beta$-galactosidase were determined by ELISA (Roche). Promoter activity was expressed as pg CAT/ng $\beta$-galactosidase to correct for differences in cell number and transfection efficiency.

Transfections of HepG2 cells with the luciferase-reporter constructs were performed in 24-wells plates with Lipofectamine Plus (Invitrogen, Groningen, Netherlands) using $0.4 \mu \mathrm{g}$ of the luciferase-reporter construct and $20 \mathrm{ng}$ of pRL-SV40 (Promega) per well (Botma et al., 2005). At $3 \mathrm{~h}$ and $24 \mathrm{~h}$ after transfection, the 
medium was refreshed and test agents were added to the fresh medium. Cell extracts were prepared at $48 \mathrm{~h}$ post-transfection. The luciferase activity in the cell extracts was determined with the FireLight kit (Perkin-Elmer, Boston MA, USA) and the Packard Top Count NXT luminometer. Data were normalized for the Renilla activity measured in the same sample.

\subsection{Transfection assays with NCI-H295R cells}

The human adrenocortical cell line NCI-H295R was obtained from Dr. B. Staels, Lille, France. Cells were cultured as described previously (Botma et al., 2007). At 24 $\mathrm{h}$ before transfection, cells were plated in 6-well plates at $50 \%$ confluence. Transfections were performed with Lipofectamine-Plus using 1.0 $\mu \mathrm{g}$ CAT reporter and $0.25 \mu \mathrm{g} /$ well RSV $\beta$-galactosidase expression plasmid per well. The cells were incubated with Br-cAMP, and promoter activity was determined as described above for the HepG2 cells.

\subsection{Immunoblotting}

Near-confluence cultures of HepG2 and NCI-H295R cells were incubated for 24 $\mathrm{h}$ with or without Br-cAMP. Nuclear extracts were prepared according to (Schreiber et al., 1989). The amount of protein in each extract was determined with the DC protein assay (Bio-Rad), using bovine serum albumin as standard. Extracts (50 $\mu \mathrm{g})$ were electrophoresed on denaturing 10\% SDS/polyacrylamide gels (Laemmli, 1970), and the separated proteins were transferred to a nitrocellulose membrane (Protean, Schleicher \& Schuell, Düsseldorf, Germany). The membrane was blocked overnight with $4 \%$ milk powder/0.05\% Tween-20 in Tris-buffered saline, and then incubated for $2 \mathrm{~h}$ with either anti-C/EBP $\beta$ (1:1000) or anti-B23 (1:10000), respectively, followed by a $1 \mathrm{~h}$ incubation with secondary antibody at 1:8000, all in blocking buffer. The secondary antibody was visualised by enhanced chemiluminescence. The images were quantified by densitometry using the GS-800 Calibrated Densitometer from BioRad. 


\subsection{Chromatin immunoprecipitation assays}

These assays were performed according to the instructions of Upstate Biotechnology (Lake Placid NY, USA) with some modifications, using a single $10-\mathrm{cm}$ culture dish of HepG2 cells for each immunoprecipitation reaction. At near-confluence, cross-links were formed with $1 \%$ formaldehyde. Thereafter, cell lysates were prepared and sonicated until DNA was sheared into $<1000 \mathrm{bp}$ fragments. An aliquot of sheared chromatin was used as input control, the remainder was diluted 10-fold in immunoprecipitation buffer (1\% Triton X-100, 2 mM EDTA, $150 \mathrm{mM} \mathrm{NaCl}, 20 \mathrm{mM}$ Tris-HCl; $\mathrm{pH} 8.0$ ). After preclearing for $30 \mathrm{~min}$ at $4^{\circ} \mathrm{C}$ with $60 \mu \mathrm{l}$ protein ASepharose beads preabsorbed with salmon sperm DNA (Upstate), the chromatin solution was incubated overnight at $4^{\circ} \mathrm{C}$ with $4 \mu \mathrm{l}$ anti-C/EBP $\beta$ antibodies. As negative control, a chromatin fraction was incubated in parallel without antibody. Then, $60 \mu \mathrm{l}$ protein A-Sepharose beads were added. After $1 \mathrm{~h}$ incubation at $4^{\circ} \mathrm{C}$, the beads were collected by centrifugation. After extensive washing, bound material was eluted with $1 \%$ SDS; $0.1 \mathrm{M} \mathrm{NaHCO}_{3}$. Cross-links were reversed by incubation for $4 \mathrm{~h}$ at $65^{\circ} \mathrm{C}$ in the presence of $0.2 \mathrm{M} \mathrm{NaCl}$, followed by incubation for $30 \mathrm{~min}$ at $65^{\circ} \mathrm{C}$ with $2 \mu \mathrm{g} / \mathrm{ml}$ RNase A in $10 \mathrm{mM}$ EDTA; $40 \mathrm{mM}$ Tris (pH 6.8). The DNA was isolated with a QIAquick PCR purification kit (QIAGEN, Hilden, Germany) and subjected to real-time quantitative PCR analysis, as described above. Amplification was done with the proximal HL promoter specific primers 5'-GGC AGT CTT CCC TAA CAA AGT ATC-3' (nt-51/-28) and 5'-TGT CCA TTT CTC CGT TTC ACC3' (nt +30/+50) and the distal HL gene specific primers 5'-CTT GGG ATT TGC TTG CTT TAT C-3' (nt -6071/-6050) and 5'-ATT TGA TGA CCT GAG AAT GAC C-3' (nt -5965/-5986). Quantitation was done by the $\Delta \mathrm{C}_{\mathrm{T}}$ method using the $1 \%$ inputreaction as a reference.

\subsection{Statistics}

Experimental data are expressed as mean \pm SD. Differences were tested for statistical significance by paired Student's $t$-test. 


\section{Results}

\subsection{Effect of cAMP on HL secretion and HL $m R N A$.}

Overnight incubation of HepG2 cells with db-cAMP and Br-cAMP resulted in a dosedependent decrease in secretion of hepatic lipase activity (Fig. 1A). With Br-cAMP, maximal inhibition of about $50 \%$ was observed at a final concentration of $0.3 \mathrm{mM}$, and a half-maximal effect was reached at less than $0.03 \mathrm{mM}$. Db-cAMP was less effective, with a similar maximal inhibition observed at about $3 \mathrm{mM}$, and a halfmaximal effect at about $0.3 \mathrm{mM}$. Over the same concentration range, 8 -bromo-cGMP did not affect hepatic lipase secretion. The inhibition of hepatic lipase secretion induced by Br-cAMP was not paralleled by a significant reduction of $\alpha_{1}$-antitrypsin secretion (Fig. 1B), or by an inhibition of overall protein synthesis or secretion (Fig. 1C). This suggests that the inhibitory effect of cAMP was rather specific for hepatic lipase.

With $0.3 \mathrm{mM}$ Br-cAMP, secretion of hepatic lipase initially proceeded unaffected. Only after $4 \mathrm{~h}$ of incubation with the cAMP homolog, hepatic lipase activity in the extracellular medium became significantly lower than in parallel controls (Fig. 2A). Between 8 and 24 h, secretion of hepatic lipase activity continued but at a much lower rate than in control incubations. Simultaneously, intracellular HL activity was reduced from $0.68 \pm 0.08$ to $0.54 \pm 0.04 \mathrm{mU} /$ well $($ mean $\pm \mathrm{SD}, \mathrm{n}=3$; $\mathrm{p}<0.05)$. For comparison, we also incubated cells with cycloheximide, which instantaneously and completely inhibited overall protein synthesis (Verhoeven et al., 1999). Here, inhibition of hepatic lipase secretion became apparent between 4 and $8 \mathrm{~h}$, and was complete thereafter (Fig. 2A). This delayed inhibition is interpreted to indicate maturation and secretion of hepatic lipase that was already present in the cells at the start of the incubation with cycloheximide (Verhoeven et al., 1999). These data suggest therefore, that synthesis and secretion of hepatic lipase continues in the presence of Br-cAMP, but at a much reduced rate. By semi-quantitative RT-PCR, HL mRNA expression was 1.5- to 2-fold less in cells incubated overnight with $0.3 \mathrm{mM}$ Br-cAMP than in parallel controls (Fig. 2B). By real-time PCR, HL mRNA in BrcAMP treated cells was $1.38 \pm 0.13$ fold less than in control cells (mean $\pm S D, n=3$; 
$\mathrm{p}<0.05)$. Hence, the inhibition of HL secretion induced by elevation of cAMP is at least partly explained by a reduction of HL mRNA expression.

\subsection{Effect of cAMP on HL promoter activity in HepG2 cells.}

To test whether reduced HL mRNA expression is the result of reduced transcription, we performed promoter-reporter assays in transiently transfected HepG2 cells. We used the proximal $-685 /+13$ and $-446 /+9$ promoter region of the human and rat HL gene, cloned in front of a luciferase and CAT reporter gene, respectively. As shown in Fig. 3A, the activity of both HL promoter-reporter constructs was 60-75\% lower in cAMP-treated cells than in parallel controls. In contrast, the activity of reporter constructs containing the viral SV40 control promoter (Fig. 3A) or the CMV control promoter (data not shown), were not reduced but rather increased by cAMP treatment. With the human HL promoter construct, maximal inhibitory effect was observed with $0.1 \mathrm{mM}$ Br-cAMP, and half-maximal effect was reached at about $0.01 \mathrm{mM}$ (Fig. 3B). Hence, HL promoter activity is similarly, or even slightly more, sensitive to inhibition by Br-cAMP as secretion of HL activity. We conclude therefore, that the inhibitory effect of cAMP elevation on HL secretion is largely explained by reduced transcription of the HL gene.

\subsection{Identification of a cAMP-responsive element in the HL promoter.}

In the best-studied cAMP responsive liver gene PEP-CK, the cAMP effect is mediated through CREB-, AP1- and C/EBP-like transcription factors (Roesler, 2000). Recently, HNF4 $\alpha$ has been shown to mediate cAMP responsiveness to the CYP7A1 gene (Song and Chiang, 2006). With the Match program (Kel et al., 2003), a number of consensus binding sites for these cAMP-sensitive transcription factors were found in both the proximal human (Fig. 4A) and rat HL promoter region (Fig. 4C). To test through which of these elements cAMP may affect HL promoter activity, serial 5'deletion constructs were generated, and tested for their ability to respond to cAMP. Statistically significant inhibition of human HL promoter activity by $0.3 \mathrm{mM} \mathrm{Br}-$ cAMP was observed with the 5'-deleted fragments up till-79 (Fig. 4B). This ruled out a major role for the putative CREB, AP1 and HNF4 consensus binding sites in 
this part of the human HL promoter. Further deletion to -39 removed the HNF1 and a putative C/EBP $\beta$ binding site, and completely abolished the Br-cAMP-induced inhibition (Fig. 4B). Instead, HL promoter activity was slightly increased by $\mathrm{Br}$ cAMP, similar to the empty control vector. For the rat HL promoter, statistically significant inhibition of promoter activity by Br-cAMP was observed with serial 5'deletions from -446 to -75 (Fig. 4D). The rat HL promoter contains a HNF1 site and an adjacent $\mathrm{C} / \mathrm{EBP} \beta$ binding site at a similar position as the human HL promoter. Further deletion of the rat HL promoter to -39 , thereby removing the HNF1 site but not the adjacent $\mathrm{C} / \mathrm{EBP} \beta$ binding site, did not affect responsiveness to Br-cAMP. However, Br-cAMP no longer inhibited transcriptional activity when the rat HL promoter was shortened to -23 , which removed this C/EBP $\beta$ binding site and the TATA box.

Comparison of the activity of 5'-deletion constructs of the human and rat HL promoter pinpointed cAMP responsiveness to a $10 \mathrm{bp}$ sequence consisting of the potential C/EBP $\beta$ binding site (Fig. 5A). Deletion of this $-45 /-36$ sequence from the human HL -685 promoter-reporter construct completely abolished responsiveness to Br-cAMP (Fig. 5B). To test whether C/EBP $\beta$ binds to this site in HepG2 cells, we performed chromatin immunoprecipitation assays using anti-C/EBP $\beta$ antibodies. When compared to the distal HL promoter fragment, and to no-antibody controls (mock), the proximal promoter region of the HL gene $(-51 /+30)$ encompassing the putative $\mathrm{C} / \mathrm{EBP} \beta$ binding site was specifically amplified from immunoprecipitated DNA (Fig. 5C). Moreover, the amount of proximal HL promoter that was immunoprecipitated from the chromatin of Br-cAMP-treated cells was reduced to approximately $50 \%$ of parallel controls $(\mathrm{p}<0.05 ; \mathrm{n}=3$ ). These data suggest an important role for the potential C/EBP $\beta$ site immediately 3' of the HNF1 site in effecting cAMP responsiveness to the human and rat HL promoter.

Next, we tested the effect of cAMP on expression of $\mathrm{C} / \mathrm{EBP} \beta$ protein in nuclear extracts of HepG2 cells, using the nucleolar protein nucleophosmin (B23) as loading control. $\mathrm{C} / \mathrm{EBP} \beta$ ran as a $45 \mathrm{kDa}$ protein, with a minor band at $20 \mathrm{kDa}$, corresponding to LAP and LIP isoforms, respectively (Fig. 6). The amount of the $45 \mathrm{kDa}$ C/EBP $\beta$ protein was reduced by approximately $50 \%$ after $24 \mathrm{~h}$ incubation of the cells with $0.3 \mathrm{mM}$ Br-cAMP. This coincided with the increased abundance of a 32 $\mathrm{kDa}$ immuno-reactive protein. The expression of the $20 \mathrm{kDa}$ isoform of $\mathrm{C} / \mathrm{EBP} \beta$ was 
not affected by cAMP. Taken together, the cAMP induced reduction in HL gene expression may be mediated by the decreased nuclear expression of the $45 \mathrm{kDa}$ $\mathrm{C} / \mathrm{EBP} \beta$ isoform.

\subsection{Effect of cAMP on HL promoter activity in adrenocortical cells.}

The human HL gene is also transcribed in human adrenocortical cells (Botma et al., 2007). In contrast to the HepG2 cells, treatment of H295R adrenocortical cell line with $0.3 \mathrm{mM}$ Br-cAMP was shown to increase HL promoter activity (Botma et al., 2007). Upon transient transfection into the H295R cells, the hHL-685 and hHL-325 constructs both showed significantly higher promoter activity when incubated with than without Br-cAMP $(\mathrm{p}<0.05 ; \mathrm{n}=3)$. Qualitatively similar results were obtained for the rat HL-446 reporter construct (Fig. 7). In nuclear extracts of the H295R cells, both 45 and $20 \mathrm{kDa} \mathrm{C} / \mathrm{EBP} \beta$ isoforms were expressed (Fig. 6). After correction for B23 in the loading control, the abundance of the $45 \mathrm{kDa}$ isoform in the H295R cells was twice as high as in HepG2 cells, whereas the abundance of the $20 \mathrm{kDa}$ isoform was slightly lower than in HepG2 cells. Incubation of the H295R cells with Br-cAMP only slightly reduced the relative amount of the $45 \mathrm{kDa}$ isoform to $90 \%$ of control, whereas the abundance of the $20 \mathrm{kDa}$ isoform and the immuno-reactive $32 \mathrm{kDa}$ protein remained unaffected. 


\section{Discussion}

Here we show that the synthesis and secretion of HL by human hepatoma HepG2 cells is strongly inhibited by prolonged incubation with membrane-permeant cAMP homologs, which mimics fasting conditions. To the best of our knowledge, HL expression in the fasted versus the well-fed state has not been compared in human individuals. In rats, expression of HL has been shown to be lower in the fasting than in the well-fed state (Peinado-Onsurbe et al., 1991, 2000; Stam et al., 1984), an effect that is shown to be mediated by adrenaline through $\alpha_{1 \mathrm{~B}}$ adrenergic receptors (Neve et al., 1998). In freshly isolated rat hepatocytes, $\alpha_{1 \mathrm{~B}}$ agonists acutely reduce hepatic lipase secretion (Neve et al., 1997; Peinado-Onsurbe et al., 1991; Schoonderwoerd et al., 1984) by inhibiting the intracellular maturation of newly synthesized hepatic lipase protein, an effect that is mediated by the increase in intracellular $\mathrm{Ca}^{2+}$ concentration (Neve et al., 1998). This acute, post-translational effect of adrenaline on HL secretion is paralleled by a similar fall in albumin secretion, and is therefore not considered to be specific for HL (Galan et al., 2002). $\alpha_{1 \text { в }}$ adrenergic agonists also elevate intracellular cAMP, which may result in an acute increase in HL secretion (Morita et al., 1994). However, we show here that elevation of cAMP results in reduction of hepatic lipase secretion. In contrast to the acute effects of elevated $\mathrm{Ca}^{2+}{ }_{\mathrm{i}}$, the effect of elevated cAMP occurs at the level of transcription. This appears to be specific for HL, as secretion of $\alpha_{1}$-antitrypsin is not affected, and transcriptional activity of some viral promoters is increased rather than reduced by cAMP. A similar reduction in rat hepatic lipase expression has been described for glucagon (Jensen et al., 1989) or parathyroid hormone (Klin et al., 1996), which both act through elevation of cAMP. We cannot exclude the possibility that these effects are the result of crosstalk between $\mathrm{cAMP}$ and $\mathrm{Ca}^{2+}$ signaling pathways. However, the finding that cAMP responsiveness is mediated through the well-known cAMP responsive transcription factor $\mathrm{C} / \mathrm{EBP} \beta$ (reviewed in Wilson and Roesler, 2002) suggests that the effects are mediated through cAMP itself.

Our study pinpoints cAMP responsiveness of the human and rat HL promoter to a potential C/EBP $\beta$ binding site. This $\mathrm{C} / \mathrm{EBP} \beta$ site is contiguous with the functionally important HNF1 binding site, and is conserved not only among human and rat, but also in the mouse, rabbit and rhesus monkey HL genes (van Deursen et 
al., 2007). C/EBP $\beta$ is highly expressed in liver, intestine, adipose and lung tissue (Lekstrom-Himes and Xanthopoulos, 1998), as well as in adrenocortical cells (this paper). We show here that cAMP-treatment reduces the nuclear expression of active $\mathrm{C} / \mathrm{EBP} \beta$ protein and simultaneously lowers $\mathrm{C} / \mathrm{EBP} \beta$ binding to the proximal $\mathrm{HL}$ promoter region in HepG2 cells. This may therefore, explain the reduced HL gene expression in the hepatoma cells. Besides active $45 \mathrm{kDa} \mathrm{C} / \mathrm{EBP} \beta$ protein (termed $\mathrm{LAP}$ ), the C/EBP $\beta$ gene also translates into a truncated $20 \mathrm{kDa}$ protein (termed LIP) that lacks the activation domain of LAP, and acts as a dominant-negative repressor. As in liver tissue (Carmona et al., 2005; Manchado et al., 1994), LIP expression in HepG2 cells is rather low compared to LAP. Although 20kDa LIP expression is not markedly affected by cAMP, its expression relative to $45-\mathrm{kDa}$ LAP is increased. The resulting increase in repressor activity of LIP may further attribute to the observed reduction in $\mathrm{HL}$ gene expression.

Our results indicate that $\mathrm{C} / \mathrm{EBP} \beta$ is a positive transactivator of the HL gene, and that the inhibition of HL gene expression by cAMP is mediated by decreased nuclear expression of $\mathrm{C} / \mathrm{EBP} \beta$. Surprisingly, cAMP failed to suppress HL promoter activity in human adrenocortical H295R cells. We show here that C/EBP $\beta$ expression in these cells is hardly affected by cAMP elevation, which may be related to the lack of CREB activity in these cells (Groussin et al., 2000). The mechanism by which cAMP reduces C/EBP $\beta$ expression in HepG2 cells remains unknown. One possibility is that phosphorylation of $\mathrm{C} / \mathrm{EBP} \beta$ by $\mathrm{CREB}$ may result in increased degradation of $\mathrm{C} / \mathrm{EBP} \beta$ protein. Alternatively, CREB may phosphorylate and activate another transactivator protein, thereby displacing $\mathrm{C} / \mathrm{EBP} \beta$ from the proximal promoter region of the HL gene.

If the in vitro observations also hold in vivo, several mechanisms appear to exist that ensure that HL expression is reduced during prolonged fasting. One wonders therefore, why it is physiologically important to lower HL expression during fasting. HL is involved in the clearance of chylomicron remnants by the liver, and indirectly in the removal of surface fragments that are generated by lipolysis of chylomicrons and VLDL (reviewed in Jansen et al., 2002). Therefore, it makes sense that HL expression is higher in the prandial fase than in the fasting state. In the prandial fase, adrenaline and glucagon levels fall, which will result in a fall in intrahepatocyte cAMP levels and thus, HL expression will rise. Although there may be an 
additional benefit to lower HL expression during prolonged fasting, we propose that the cAMP effects observed are a reflection of the increased expression of HL during the prandial state mediated, among others, by the lowering of intra-hepatic cAMP concentration. 


\section{References}

Baynes, C., Henderson, A.D., Anyaoku, V., Richmond, W., Hughes, C.L., Johnston, D.G., Elkeles, R.S., 1991. The role of insulin insensitivity and hepatic lipase in the dyslipidaemia of type 2 diabetes. Diabet. Med. 8, 560-566.

Baynes, C., Henderson, A.D., Richmond, W., Johnston, D.G., Elkeles, R.S., 1992. The response of hepatic lipase and serum lipoproteins to acute hyperinsulinaemia in type 2 diabetes. Eur. J. Clin. Invest. 22, 341-346.

Botma, G.J., Heuveling, M., Lamers, J.M., Jansen, H., Verhoeven, A.J., 2007. Cloning, expression, and promoter analysis of hepatic lipase derived from human hyperplastic adrenals: evidence for alternative mRNA splicing. Cell. Biochem. Biophys. 47, 149-158.

Botma, G.J., van Deursen, D., Vieira, D., van Hoek, M., Jansen, H., Verhoeven, A.J., 2005. Sterolregulatory-element binding protein inhibits upstream stimulatory factor-stimulated hepatic lipase gene expression. Atherosclerosis 179, 61-67.

Botma, G.J., Verhoeven, A.J., Jansen, H., 2001. Hepatic lipase promoter activity is reduced by the C480T and G-216A substitutions present in the common LIPC gene variant, and is increased by Upstream Stimulatory Factor. Atherosclerosis 154, 625-632.

Carmona, M.C., Hondares, E., Rodriguez de la Concepcion, M.L., Rodriguez-Sureda, V., PeinadoOnsurbe, J., Poli, V., Iglesias, R., Villarroya, F., Giralt, M., 2005. Defective thermoregulation, impaired lipid metabolism, but preserved adrenergic induction of gene expression in brown fat of mice lacking C/EBPbeta. Biochem. J. 389, 47-56.

Carr, M.C., Hokanson, J.E., Deeb, S.S., Purnell, J.Q., Mitchell, E.S., Brunzell, J.D., 1999. A hepatic lipase gene promoter polymorphism attenuates the increase in hepatic lipase activity with increasing intra-abdominal fat in women. Arterioscler. Thromb. Vasc. Biol. 19, 2701-2707.

Chomczynski, P., Sacchi, N., 1987. Single-step method of RNA isolation by acid guanidinium thiocyanate-phenol-chloroform extraction. Anal. Biochem. 162, 156-159.

Cominacini, L., Garbin, U., Davoli, A., Campagnola, M., De Santis, A., Pasini, C., Pastorino, A.M., Bosello, O., 1993. High-density lipoprotein cholesterol concentrations and postheparin hepatic and lipoprotein lipases in obesity: relationships with plasma insulin levels. Ann. Nutr. Metab. 37, 175-184.

Datta, S., Luo, C.C., Li, W.H., VanTuinen, P., Ledbetter, D.H., Brown, M.A., Chen, S.H., Liu, S.W., Chan, L., 1988. Human hepatic lipase. Cloned cDNA sequence, restriction fragment length polymorphisms, chromosomal localization, and evolutionary relationships with lipoprotein lipase and pancreatic lipase. J. Biol. Chem. 263, 1107-1110.

Despres, J.P., Ferland, M., Moorjani, S., Nadeau, A., Tremblay, A., Lupien, P.J., Theriault, G., Bouchard, C., 1989. Role of hepatic-triglyceride lipase activity in the association between intra-abdominal fat and plasma HDL cholesterol in obese women. Arteriosclerosis 9, 485-492.

Galan, X., Peinado-Onsurbe, J., Robert, M.Q., Soley, M., Llobera, M., Ramirez, I., 2002. Acute regulation of hepatic lipase secretion by rat hepatocytes. Biochem. Cell Biol. 80, 467-474.

Groussin, L., Massias, J.F., Bertagna, X., Bertherat, J., 2000. Loss of expression of the ubiquitous transcription factor cAMP response element-binding protein (CREB) and compensatory overexpression of the activator CREMtau in the human adrenocortical cancer cell line H295R. J. Clin. Endocrinol. Metab. 85, 345-354.

Higuchi, R., Krummel, B., Saiki, R.K., 1988. A general method of in vitro preparation and specific mutagenesis of DNA fragments: study of protein and DNA interactions. Nucleic Acids Res. 16, 7351-7367.

Hornbuckle, L.A., Everett, C.A., Martin, C.C., Gustavson, S.S., Svitek, C.A., Oeser, J.K., Neal, D.W., Cherrington, A.D., O'Brien, R.M., 2004. Selective stimulation of G-6-Pase catalytic subunit but not G-6-P transporter gene expression by glucagon in vivo and cAMP in situ. Am. J. Physiol. Endocrinol. Metab. 286, E795-808.

Isaacs, A., Sayed-Tabatabaei, F.A., Njajou, O.T., Witteman, J.C., van Duijn, C.M., 2004. The -514 C$>$ T hepatic lipase promoter region polymorphism and plasma lipids: a meta-analysis. J. Clin. Endocrinol. Metab. 89, 3858-3863.

Jansen, H., de Greef, W.J., 1988. L-type lipase activity in ovaries of superovulated rats. Relation to cholesterol homeostasis. Mol. Cell. Endocrinol. 57, 7-15.

Jansen, H., Verhoeven, A.J., Sijbrands, E.J., 2002. Hepatic lipase: a pro- or anti-atherogenic protein? J. Lipid Res. 43, 1352-1362.

Jansen, H., Verhoeven, A.J., Weeks, L., Kastelein, J.J., Halley, D.J., van den Ouweland, A., Jukema, J.W., Seidell, J.C., Birkenhager, J.C., 1997. Common C-to-T substitution at position -480 of 
the hepatic lipase promoter associated with a lowered lipase activity in coronary artery disease patients. Arterioscler. Thromb. Vasc. Biol. 17, 2837-2842.

Jensen, E., Hansson, P., Floren, C.H., Nilsson, A., Nilsson-Ehle, P., 1989. Cell-density-dependent release of hepatic lipase from cultured rat hepatocytes. Horm. Metab. Res. 21, 4-7.

Katzel, L.I., Coon, P.J., Busby, M.J., Gottlieb, S.O., Krauss, R.M., Goldberg, A.P., 1992. Reduced HDL2 cholesterol subspecies and elevated postheparin hepatic lipase activity in older men with abdominal obesity and asymptomatic myocardial ischemia. Arterioscler. Thromb. 12, 814-823.

Kel, A.E., Gossling, E., Reuter, I., Cheremushkin, E., Kel-Margoulis, O.V., Wingender, E., 2003. MATCH: A tool for searching transcription factor binding sites in DNA sequences. Nucleic Acids Res. 31, 3576-3579.

Klin, M., Smogorzewski, M., Ni, Z., Zhang, G., Massry, S.G., 1996. Abnormalities in hepatic lipase in chronic renal failure: role of excess parathyroid hormone. J. Clin. Invest. 97, 2167-2173.

Kost, D.P., DeFrances, M.C., Lee, C.R., Michalopoulos, G.K., 1992. Patterns of alpha-1-adrenergic receptor expression in regenerating and neoplastic hepatic tissue. Pathobiology 60, 303-308.

Laemmli, U.K., 1970. Cleavage of structural proteins during the assembly of the head of bacteriophage T4. Nature 227, 680-685.

Lekstrom-Himes, J., Xanthopoulos, K.G., 1998. Biological role of the CCAAT/enhancer-binding protein family of transcription factors. J. Biol. Chem. 273, 28545-28548.

Manchado, C., Yubero, P., Vinas, O., Iglesias, R., Villarroya, F., Mampel, T., Giralt, M., 1994. CCAAT/enhancer-binding proteins alpha and beta in brown adipose tissue: evidence for a tissue-specific pattern of expression during development. Biochem J 302, 695-700.

Matys, V., Fricke, E., Geffers, R., Gossling, E., Haubrock, M., Hehl, R., Hornischer, K., Karas, D., Kel, A.E., Kel-Margoulis, O.V., Kloos, D.U., Land, S., Lewicki-Potapov, B., Michael, H., Munch, R., Reuter, I., Rotert, S., Saxel, H., Scheer, M., Thiele, S., Wingender, E., 2003. TRANSFAC: transcriptional regulation, from patterns to profiles. Nucleic Acids Res. 31, 374378.

Mirel, R.D., Morris, H.P., DiAugustine, R.P., 1978. Membrane receptor function and the loss of glucagon-stimulated adenylate cyclase activity in hepatomas. Endocrinology 102, 1237-1246.

Morgan, N.G., Waynick, L.E., Exton, J.H., 1983. Characterisation of the alpha 1-adrenergic control of hepatic cAMP in male rats. Eur. J. Pharmacol. 96, 1-10.

Morita, T., Sakata, K., Kanagawa, A., Ueki, H., 1994. Stimulatory release of hepatic lipase activity from cultured rat hepatocytes by sodium orthovanadate: rapid increase in cyclic adenosine monophosphate content. Biol. Pharm. Bull. 17, 577-580.

Neve, B.P., Verhoeven, A.J., Jansen, H., 1997. Acute effects of adrenaline on hepatic lipase secretion by rat hepatocytes. Metabolism 46, 76-82.

Neve, B.P., Verhoeven, A.J., Kalkman, I., Jansen, H., 1998. Maturation and secretion of rat hepatic lipase is inhibited by alpha1B-adrenergic stimulation through changes in $\mathrm{Ca} 2+$ homoeostasis: thapsigargin and EGTA both mimic the effect of adrenaline. Biochem. J. 330, 701-706.

Nie, L., Wang, J., Clark, L.T., Tang, A., Vega, G.L., Grundy, S.M., Cohen, J.C., 1998. Body mass index and hepatic lipase gene (LIPC) polymorphism jointly influence postheparin plasma hepatic lipase activity. J. Lipid Res. 39, 1127-1130.

Nomura, T., Kondo, H., Hasegawa, S., Watanabe, T., Yokoyama, R., Ukai, K., Tachibana, M., SumiIchinose, C., Nomura, H., Hagino, Y., 1993. Alpha 1B-adrenoceptor-mediated stimulation of $\mathrm{Ca} 2+$ mobilization and cAMP accumulation in isolated rat hepatocytes. Eur. J. Pharmacol. 246, 113-120.

Peinado-Onsurbe, J., Julve, J., Galan, X., Llobera, M., Ramirez, I., 2000. Effect of fasting on hepatic lipase activity in the liver of developing rats. Biol. Neonate 77, 131-138.

Peinado-Onsurbe, J., Soler, C., Galan, X., Poveda, B., Soley, M., Llobera, M., Ramirez, I., 1991. Involvement of catecholamines in the effect of fasting on hepatic endothelial lipase activity in the rat. Endocrinology 129, 2599-2606.

Perret, B., Mabile, L., Martinez, L., Terce, F., Barbaras, R., Collet, X., 2002. Hepatic lipase: structure/function relationship, synthesis, and regulation. J. Lipid Res. 43, 1163-1169.

Pollare, T., Vessby, B., Lithell, H., 1991. Lipoprotein lipase activity in skeletal muscle is related to insulin sensitivity. Arterioscler. Thromb. 11, 1192-1203.

Rich, B.E., Steitz, J.A., 1987. Human acidic ribosomal phosphoproteins P0, P1, and P2: analysis of cDNA clones, in vitro synthesis, and assembly. Mol. Cell Biol. 7, 4065-4074.

Roesler, W.J., 2000. What is a cAMP response unit? Mol. Cell. Endocrinol. 162, 1-7.

Rufibach, L.E., Duncan, S.A., Battle, M., Deeb, S.S., 2006. Transcriptional regulation of the human hepatic lipase (LIPC) gene promoter. J. Lipid Res. 47, 1463-1477. 
Sanae, F., Kohei, K., Nomura, M., Miyamoto, K., 1992. Studies on responsiveness of hepatoma cells to catecholamines. VI. Characteristics of adrenoceptors and adenylate cyclase response in rat ascites hepatoma cells and human hepatoma cells. J. Pharmacobiodyn 15, 303-309.

Schoonderwoerd, K., Hulsmann, W.C., Jansen, H., 1984. Regulation of liver lipase. II. Involvement of the alpha 1-receptor. Biochim. Biophys. Acta 795, 481-486.

Schreiber, E., Matthias, P., Muller, M.M., Schaffner, W., 1989. Rapid detection of octamer binding proteins with 'mini-extracts', prepared from a small number of cells. Nucleic Acids Res. 17, 6419.

Song, K.H., Chiang, J.Y., 2006. Glucagon and cAMP inhibit cholesterol 7alpha-hydroxylase (CYP7A1) gene expression in human hepatocytes: discordant regulation of bile acid synthesis and gluconeogenesis. Hepatology 43, 117-125.

Stam, H., Schoonderwoerd, K., Breeman, W., Hulsmann, W.C., 1984. Effects of hormones, fasting and diabetes on triglyceride lipase activities in rat heart and liver. Horm. Metab. Res. 16, 293-297.

van Deursen, D., Botma, G.J., Jansen, H., Verhoeven, A.J., 2007. Comparative genomics and experimental promoter analysis reveal functional liver-specific elements in mammalian hepatic lipase genes. BMC Genomics 8, 99.

Verhoeven, A.J., Carling, D., Jansen, H., 1994. Hepatic lipase gene is transcribed in rat adrenals into a truncated mRNA. J. Lipid Res. 35, 966-975.

Verhoeven, A.J., Jansen, H., 1990. Secretion of rat hepatic lipase is blocked by inhibition of oligosaccharide processing at the stage of glucosidase I. J. Lipid Res. 31, 1883-1893.

Verhoeven, A.J., Neve, B.P., Jansen, H., 1999. Secretion and apparent activation of human hepatic lipase requires proper oligosaccharide processing in the endoplasmic reticulum. Biochem. J. 337, 133-140.

Vieira-van Bruggen, D., Kalkman, I., van Gent, T., van Tol, A., Jansen, H., 1998. Induction of adrenal scavenger receptor BI and increased high density lipoprotein-cholesteryl ether uptake by in vivo inhibition of hepatic lipase. J. Biol. Chem. 273, 32038-32041.

Wilson, H.L., Roesler, W.J., 2002. CCAAT/enhancer binding proteins: do they possess intrinsic cAMP-inducible activity? Mol. Cell. Endocrinol. 188, 15-20. 


\section{LEGENDS TO FIGURES}

\section{Fig. 1: Effect of cAMP homologs on protein synthesis and secretion of HL and} $\alpha_{1}$-antitrypsin by HepG2 cells.

In A, HepG2 cells were incubated overnight with medium containing heparin and the indicated final concentration of Br-cAMP (•), Br-cGMP (o) or dibutyryl-cyclic AMP ( $\square)$. At the end of the incubation, HL activity was determined in the extracellular medium. Data are expressed as \% of the HL activity in the extracellular medium of parallel control incubations $(100 \%=0.79 \pm 0.05 \mathrm{mU} /$ well; mean $\pm \mathrm{SD}, \mathrm{n}=3)$, and are mean \pm SD for three independent experiments. In B and C, HepG2 cells were incubated with the indicated concentration of $\mathrm{Br}$-cAMP in the presence of $80 \mu \mathrm{Ci} / \mathrm{ml}$ $\operatorname{Tran}^{35} \mathrm{~S}$-label. At the end of the incubation, cell-free media and cell lysates were prepared. In B, $\alpha_{1}$-antitrypsin was immunoprecipitated from the cell-free media, and the ${ }^{35}$ S-label was quantified after SDS-PAGE by phosphorimaging. In C, incorporation of ${ }^{35} \mathrm{~S}$-label in total protein in cell free media $(\bullet)$ and cell lysates (o) was determined by TCA precipitation, and expressed as percentage of total ${ }^{35} \mathrm{~S}$ radioactivity in each fraction. Data are mean $\pm S D ; n=3$.

\section{Fig. 2: Effect of Br-cAMP on HL secretion and HL mRNA in HepG2 cells.}

In A, HepG2 cells were incubated for the indicated time with heparin without further additions (o), or with $0.3 \mathrm{mM} \mathrm{Br-cAMP}(\bullet)$ or $10 \mu \mathrm{g} / \mathrm{ml}$ cycloheximide ( $\square$ ). Hepatic lipase activity was determined in the extracellular medium. Data are mean \pm SD for three independent experiments. In B, cells were incubated for $24 \mathrm{~h}$ without or with 0.3 $\mathrm{mM}$ Br-cAMP (upper and lower lane, respectively), and then total cell RNA was prepared. HL mRNA expression was determined by semiquantitative RT-PCR, in which $0.5 \mu \mathrm{g}$ total cell RNA was mixed with known amounts of a HL cRNA (given in attomoles) that lack an internal 80nt fragment (Verhoeven et al., 1994). After RTPCR, the amplimers of HL mRNA and the HL-cRNA (596 and 516 bp, respectively) were separated by agarose gel electrophoresis. When signal intensities of both amplimers within a single RT-PCR mixture are identical, the amount of HL mRNA is identical to the amount of added HL-cRNA (indicated by the arrows). Data are representative of two similar experiments. 
Fig. 3: Inhibition of HL promoter activity by Br-cAMP in transfected HepG2 cells.

In A, HepG2 cells were transfected with the indicated promoter-CAT constructs, and then incubated without or with $0.3 \mathrm{mM} \mathrm{Br}$-cAMP for $44 \mathrm{~h}$ (open and hatched bars, respectively). Then, cell lysates were prepared and analysed for CAT and $\beta$ galactosidase levels. In B, HepG2 cells were transfected with the hHL-685 reporter construct, and then incubated for $44 \mathrm{~h}$ with the indicated concentration of Br-cAMP. Promoter activities were expressed as the ratio between CAT and $\beta$-galactosidase level measured in the lysate, except for the data with the SV40-promoter constructs, which are expressed as the ratio divided by 10 . Data are mean \pm SD for three independent experiments, each performed in quadruplicate.

Fig. 4: Identification of the cAMP-responsive elements in the human and rat $\mathrm{HL}$ promoter region by serial 5'-deletions.

A en $\mathrm{C}$ give a schematic representation of the human and rat HL promoter constructs, respectively. The orientation and approximate binding sites for putative cAMPresponsive transcription factors identified by the Match program (core similarity > 0.85; matrix similarity > 0.90) (Kel et al., 2003) are indicated by the arrows. In addition, the DR1 and DR4 sites involved in HNF4 $\alpha$ binding are also indicated (Rufibach et al., 2006). Based on the locations of these binding sites, 5'-deletions were generated and tested for promoter activity in the absence and presence of 0.3 mM Br-cAMP. B and D show the cAMP effect on the 5'-deletion constructs made from the human and rat HL promoter region, respectively. Promoter activity in the presence of Br-cAMP was expressed as percentage of promoter activity in its absence. Data are mean \pm SD for 3-5 independent experiments. *: statistically significant effect of $\operatorname{Br}-\mathrm{cAMP}(\mathrm{p}<0.05)$ 


\section{Fig. 5: cAMP responsiveness of the $\mathrm{HL}$ gene resides in a potential C/EBP $\beta$} consensus-binding site.

In A, the proximal promoter region of the human and rat HL gene (-66/-20 and -58/15 region, respectively) was aligned, and conserved nucleotides were indicated by the asterisks. The TATA box is given by a horizontal line. The HNF1 $\alpha$ and C/EBP $\beta$ consensus binding site is taken from the Transfac database (Matys et al., 2003), and given in the IUPAC 15-letter code on top of the aligned sequence. The upstream part and the exact 5'-end of the various human and rat promoter fragments used in reporter assays is aligned to the sequence, and drawn schematically by the horizontal bars. Open bars indicate constructs whose promoter activity is inhibited by cAMP (+), whereas closed bars indicate the constructs that are no longer responsive to cAMP (-). In B, cAMP responsiveness of human HL (-685/+13)-reporter plasmid and two independent clones with an internally deleted C/EBP $\beta$ binding site (-45/-36) was determined as described in the legends to Fig. 4B. Data are expressed as percentage of luciferase activity in control cells, and are means \pm SD for three independent experiments each performed in quadruplicate. In $\mathrm{C}$, binding of $\mathrm{C} / \mathrm{EBP} \beta$ to a distal (left panel) and proximal (right panel) part of the upstream region of the HL gene in control cells (open bars) and $0.3 \mathrm{mM}$ Br-cAMP-treated HepG2 cells (closed bars) was determined by chromatin immunoprecipitation assays using anti-C/EBP $\beta$ antibodies $(\alpha \mathrm{C} / \mathrm{EBP} \beta)$ or no antibodies (mock). Data are expressed as $\%$ of input DNA, and are means \pm SD for three independent experiments. *: statistically significant effect of $\mathrm{Br}-$ cAMP $(\mathrm{p}<0.05)$

\section{Fig. 6: Effect of Br-cAMP on C/EBP $\beta$ expression in HepG2 and H295R cells.}

Cells were incubated for $24 \mathrm{~h}$ without (-) or with $0.3 \mathrm{mM} \mathrm{Br-cAMP}(+)$, and then nuclear extracts were prepared. Of each fraction, $50 \mu \mathrm{g}$ protein was immunoblotted with anti-C/EBP $\beta$ and anti-B23 primary antibodies. The position of the molecular size markers (in $\mathrm{kDa}$ ) is indicated. The positions of $\mathrm{C} / \mathrm{EBP} \beta$ proteins corresponding to LAP (45 kDa) and LIP (20 kDa) are indicated by the arrows, and of a immuno-related protein $(32 \mathrm{kDa})$ by the arrowhead. The band at $47 \mathrm{kDa}$ is a crossreacting band (SantaCruz). 
Fig. 7: Effect of Br-cAMP on HL promoter activity in transfected H295R cells. Experiments were performed as described in the legends to Fig. 3. Promoter activities are expressed relative to the $\mathrm{CAT} / \beta$-galactosidase ratio observed with the empty promoter construct, and are mean \pm SD for three independent experiments, each performed in triplicate. 

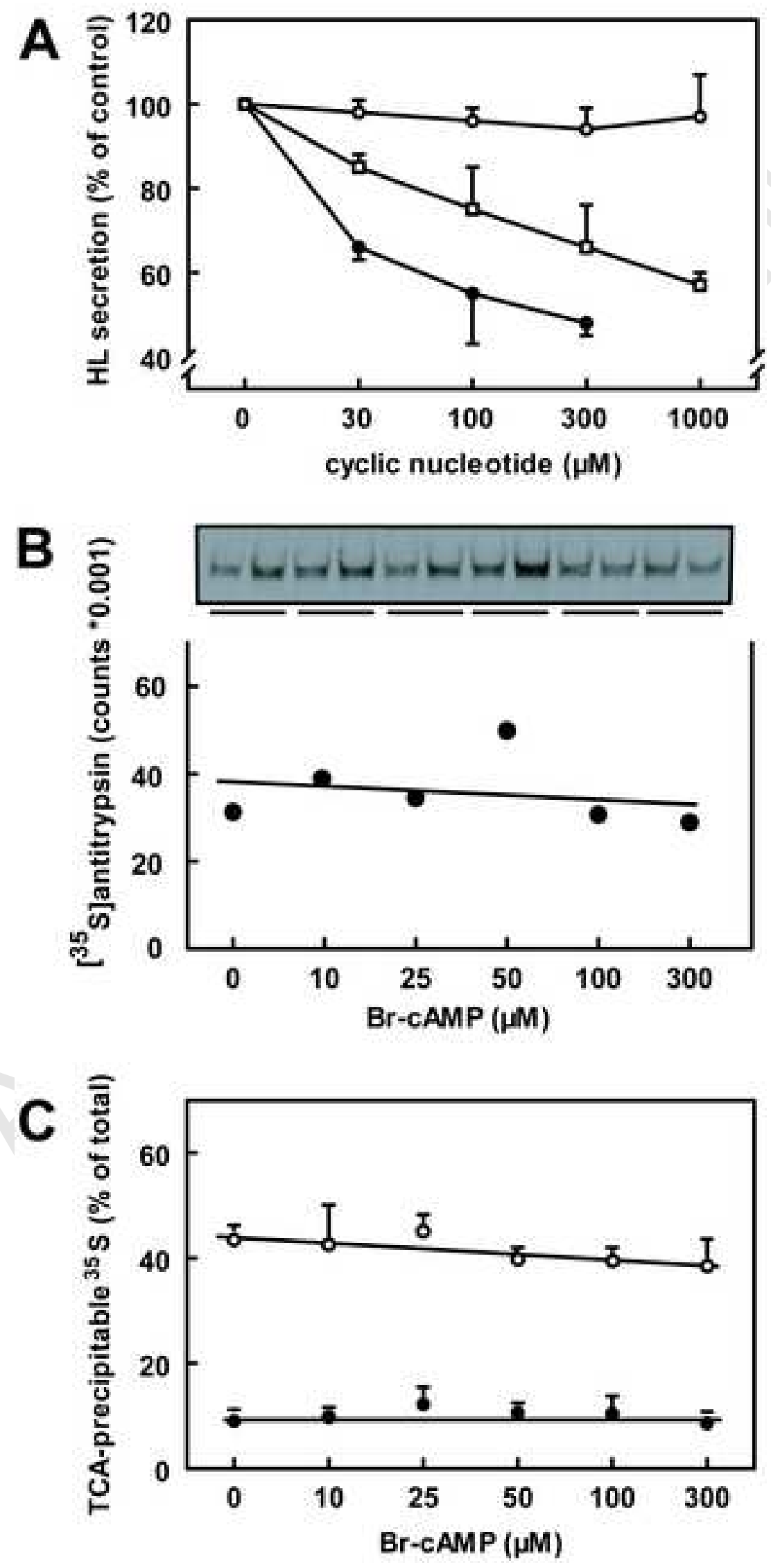
A

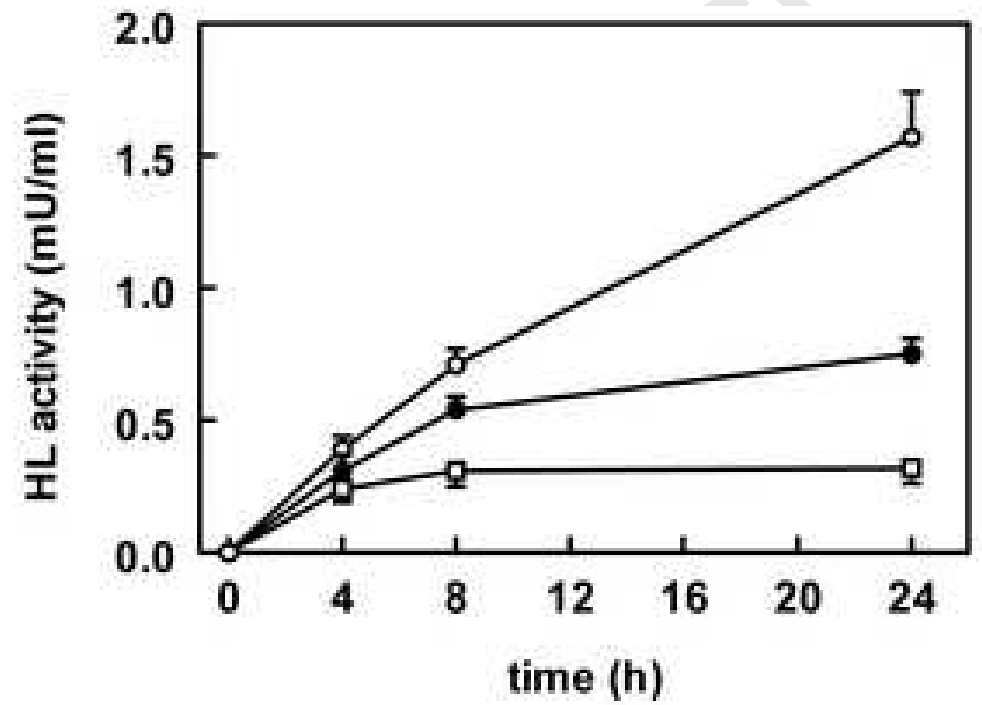

B

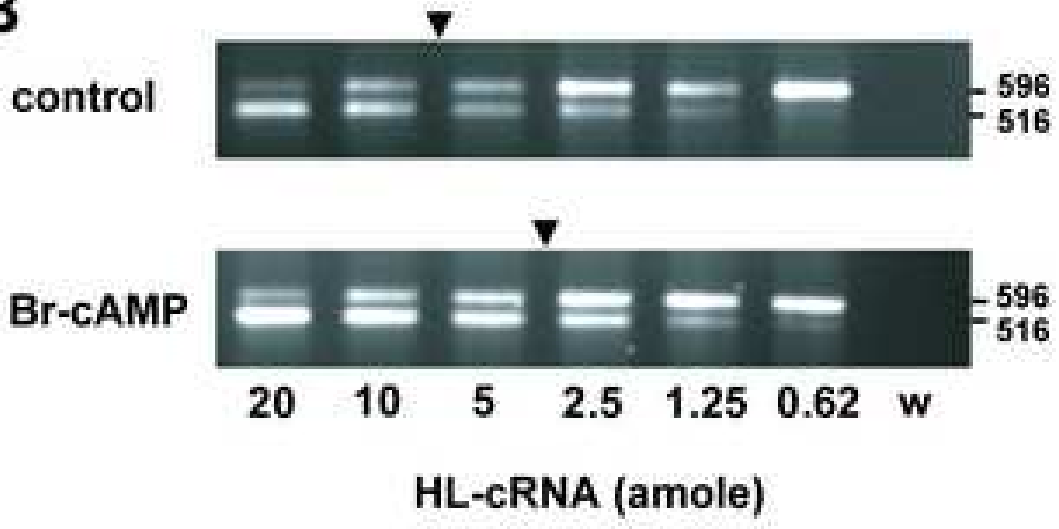




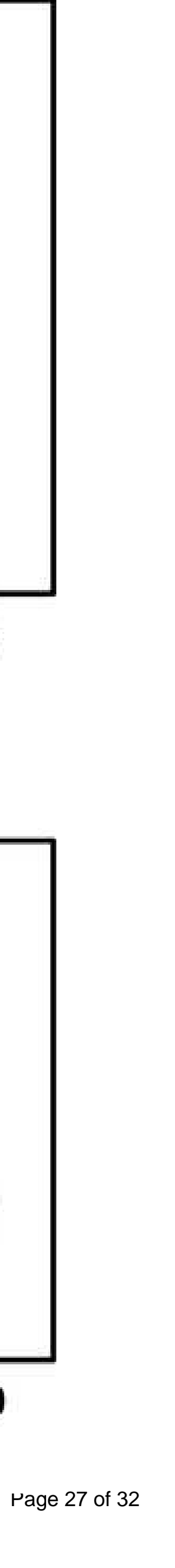

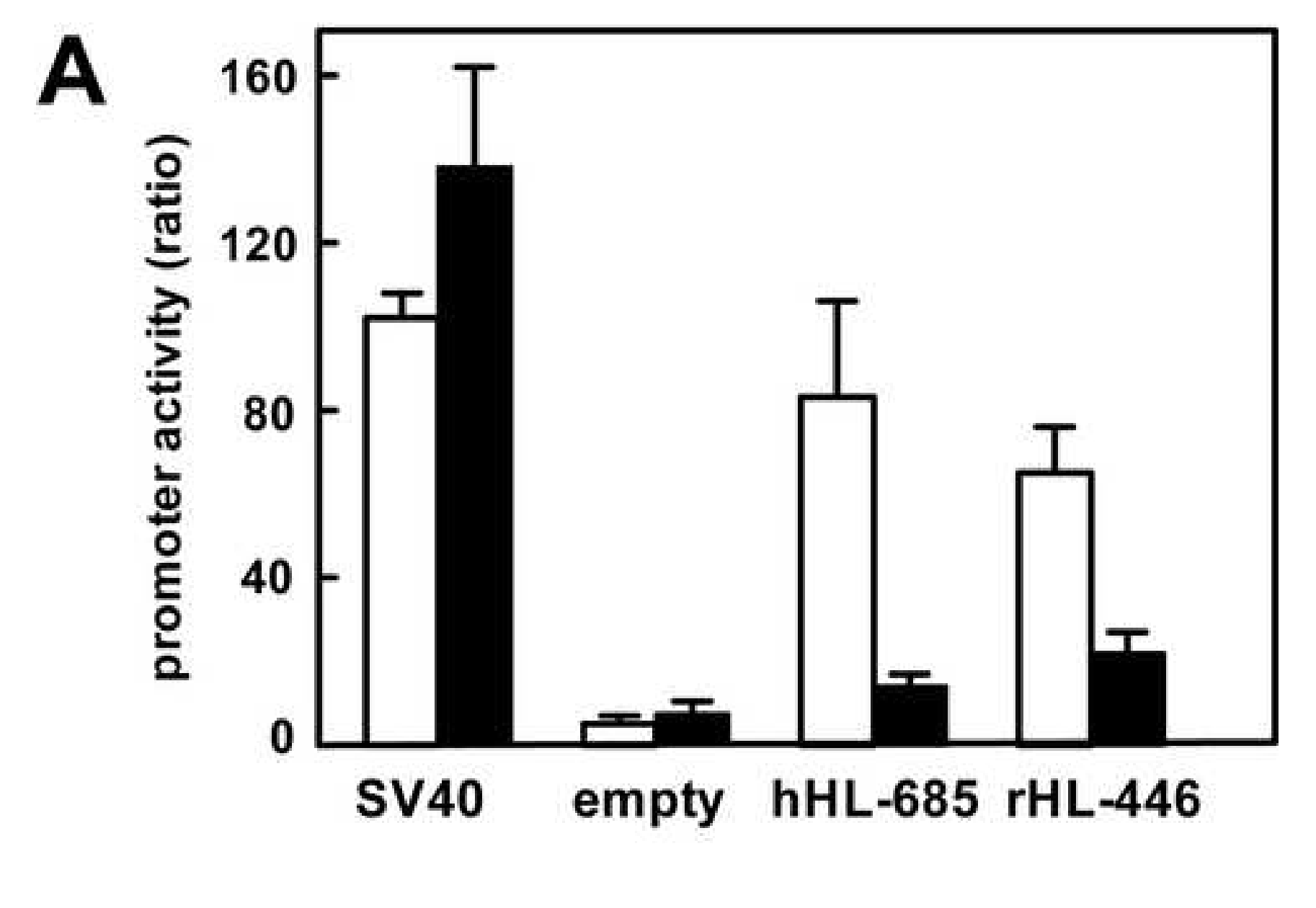

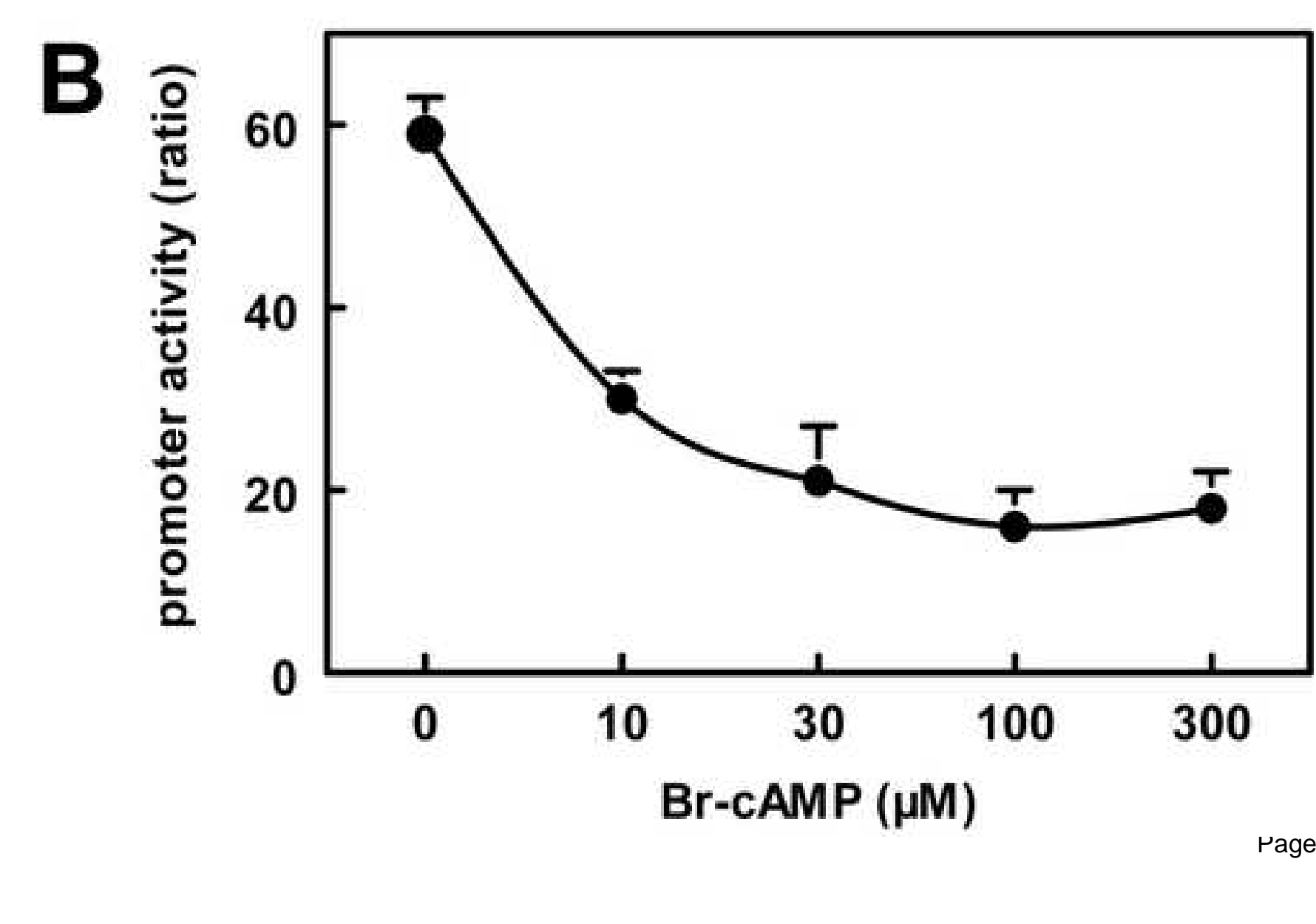

Figure 3

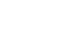

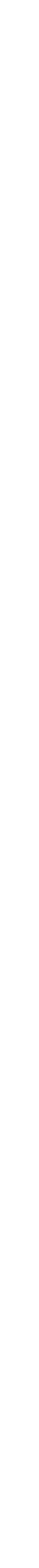
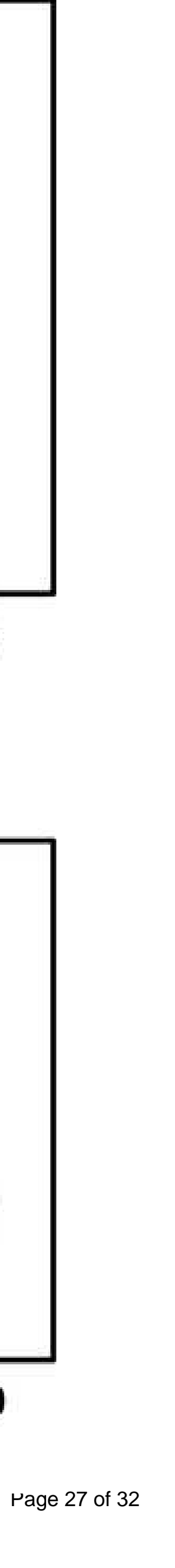
A

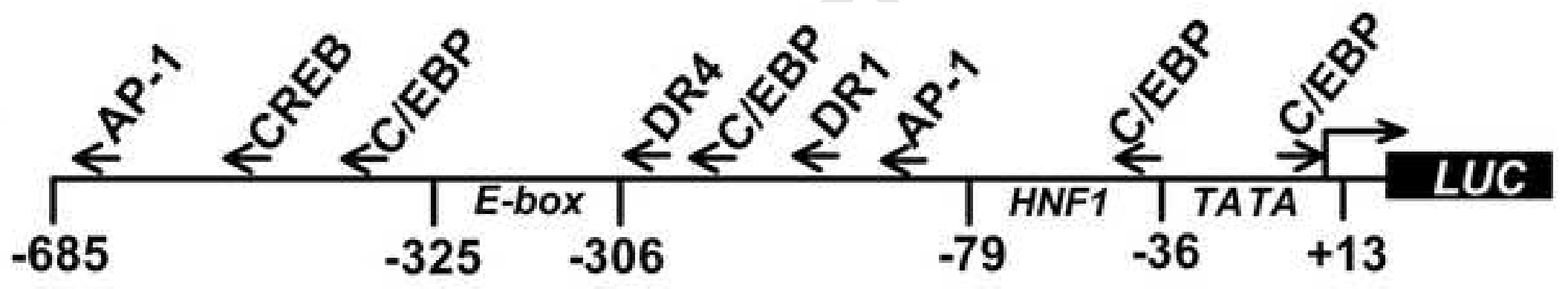

B

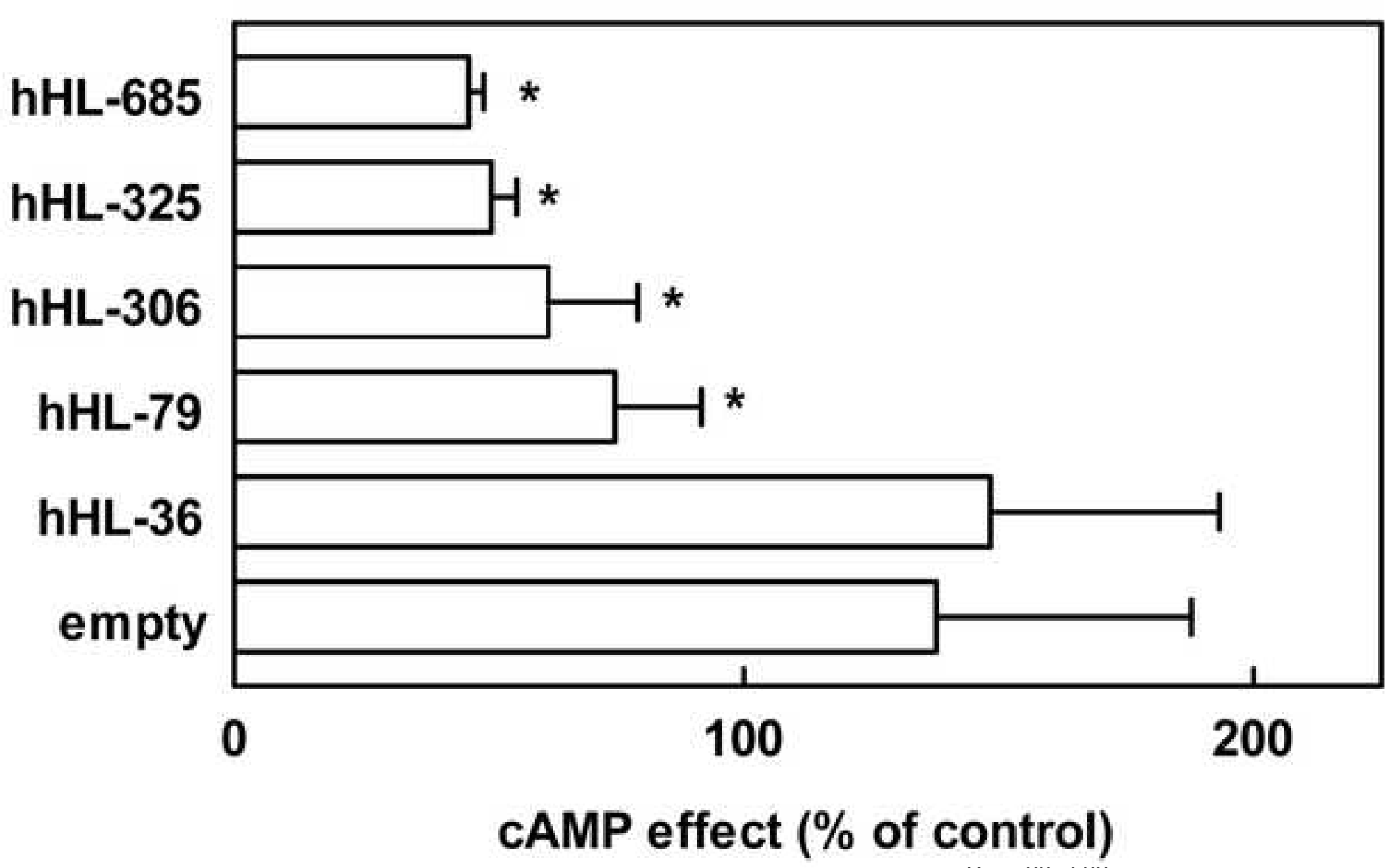


C

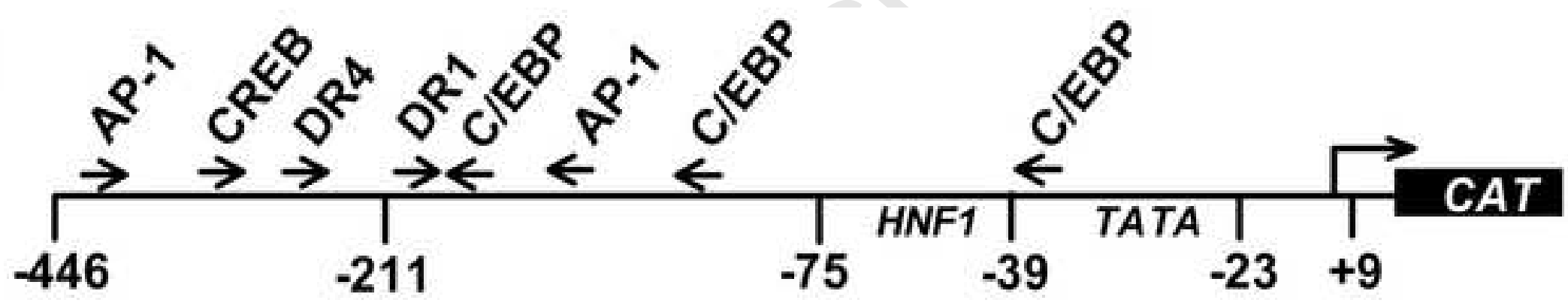

D

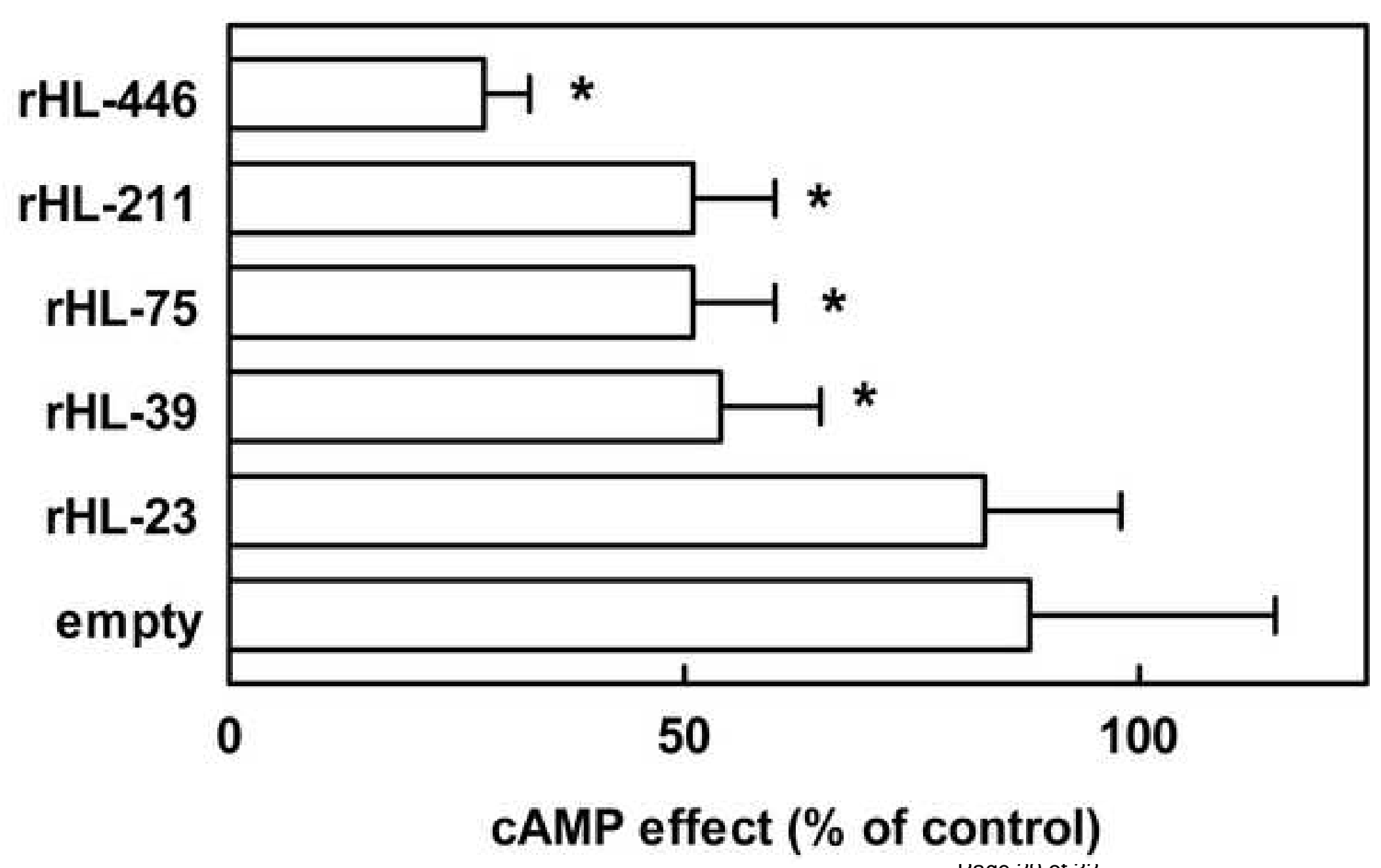


A HNF1 C/EBPB TATA

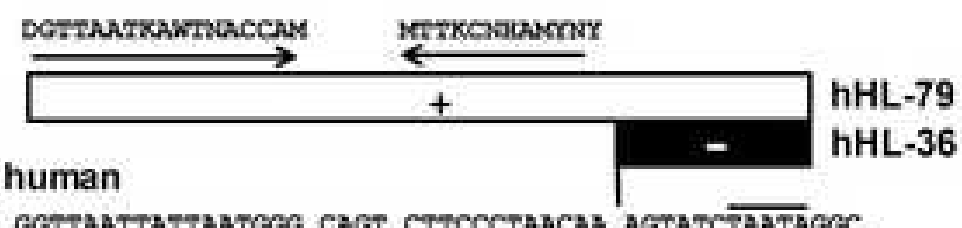

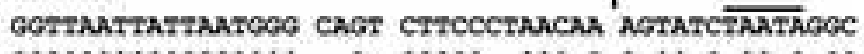

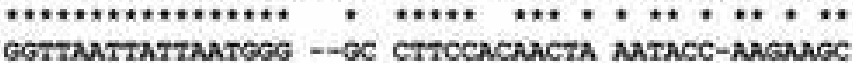

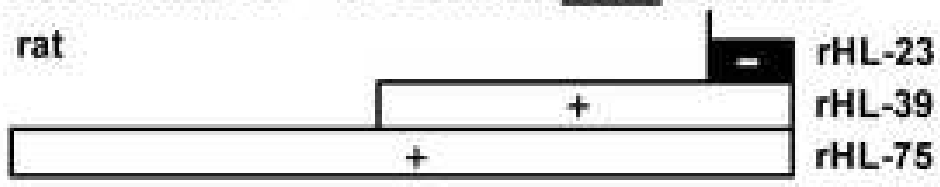

B

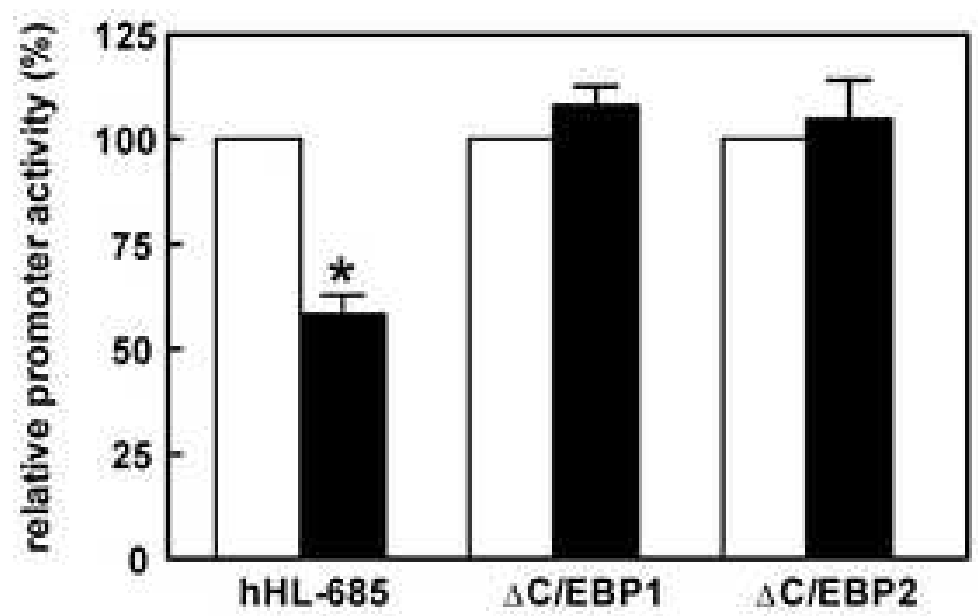

C

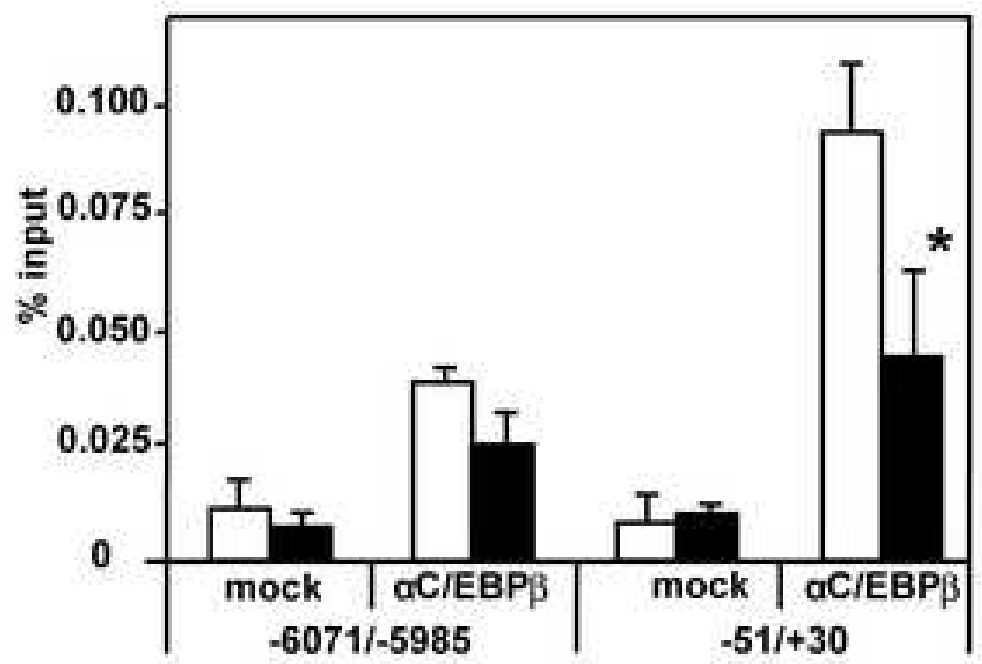


HepG2

\section{H295R}

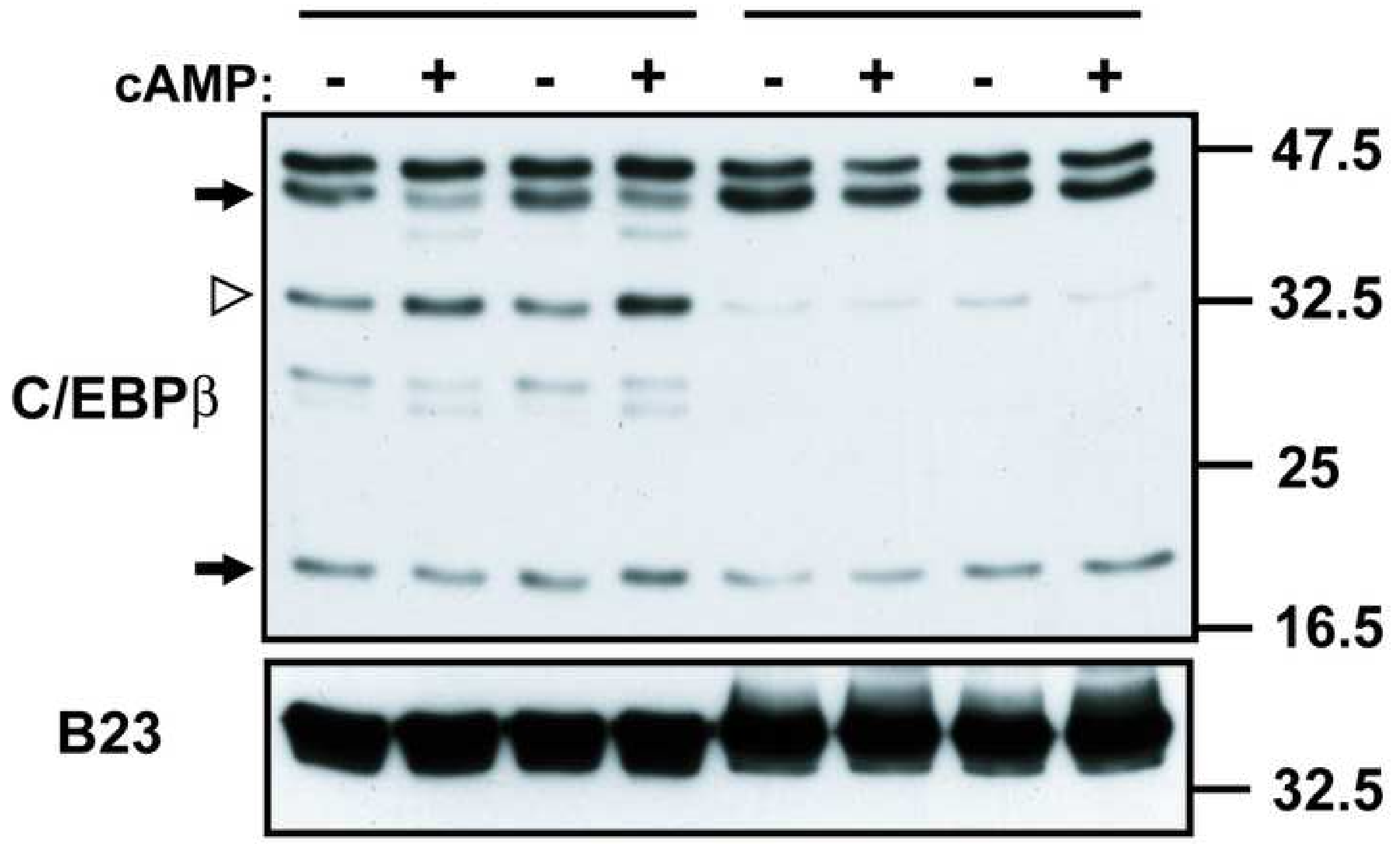




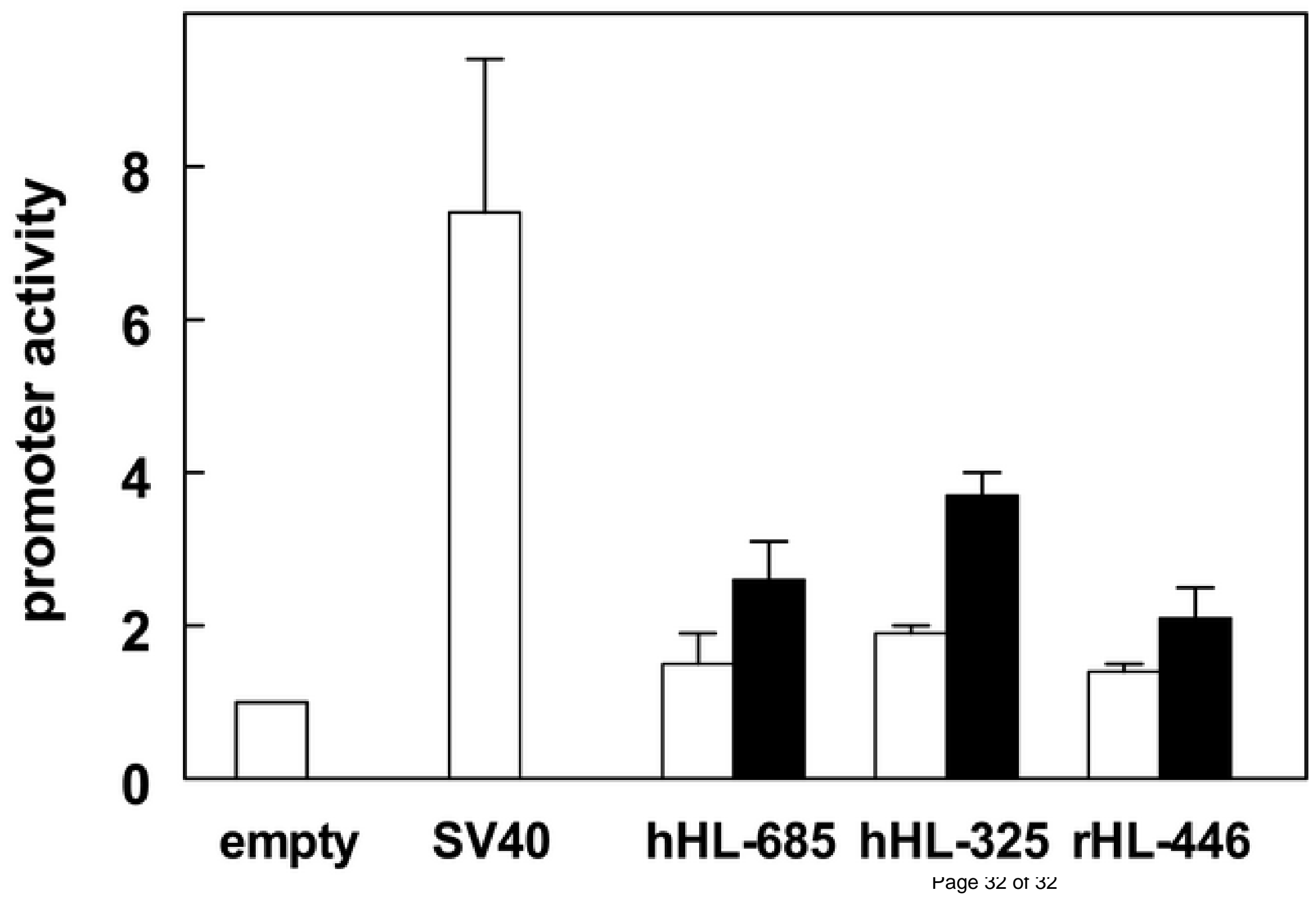

rage 32 оा 32 